\title{
Lentibulariaceae, Serra de São José, Minas Gerais, Brazil
}

\author{
Nílber Gonçalves da Silva ${ }^{1 *}$, Ruy José Válka Alves ${ }^{1}$, Jorge Fontella Pereira ${ }^{1}$ and Fernando Rivadavia ${ }^{2}$ \\ 1 Museu Nacional, Universidade Federal do Rio de Janeiro, Departamento de Botânica. Quinta da Boa Vista. CEP 20940-040. Rio de Janeiro, RJ, \\ Brasil. \\ 2 Daniel Burnham Ct; San Francisco, 94109, CA, USA. \\ * Corresponding author. E-mail: nilberius@gmail.com
}

\begin{abstract}
The Serra de São José is a mountain range within Cerrado (Brazilian savanna) biome, situated in the south of Minas Gerais state, Brazil. The predominant vegetation of the study area is campo rupestre (Brazilian rocky savanna). The latter formation, better known from the Espinhaço Chain, is the scene of many speciation events and comprises several rare species. Thirteen species of the family Lentibulariaceae belonging to the two genera occurring in Brazil are listed, briefly diagnosed, and ecologically commented herein.
\end{abstract}

\section{INTRODUCTION}

The campos rupestres form a mosaic of rocky savannas concentrated mainly along the Espinhaço chain, on the Brazilian shield. Though the Serra de São José lies over 100 $\mathrm{km}$ to the south of the Espinhaço chain, the campo rupestre flora of this relatively small range comprises several endemic plant taxa (Alves and Kolbek 2009). The variety of permanently or temporarily humid environments in these ecosystems makes this vegetation complex favorable to the growth of numerous species of carnivorous plants. These have adapted to poor waterlogged soils with low available Nitrogen - a common condition for the litholic soils of Minas Gerais state. As a part of a floristic project conducted by the Department of Botany of the National Museum, and of the MSc dissertation of the first author, this survey aims to contribute to the floristics of campos rupestres and to the taxonomy of Brazilian carnivorous plant taxa.

The family Lentibulariaceae is represented in Brazil and in the study area by two genera: Genlisea A. St.-Hil. and Utricularia L.

\section{Materials ANd Methods \\ Study Site}

The Serra de São José is a small range which consists of several mountains with elevations from 900 to 1,430 $\mathrm{m}$ a.s.l., aligned from SSW to NNE just NE of the town of Tiradentes and W of Prados, state of Minas Gerais, Brazil (Figure 1). The range is less than $2 \mathrm{~km}$ wide and roughly $15 \mathrm{~km}$ long. The top and a large part of its flanks are covered by campo rupestre vegetation, occasionally interrupted by gallery forest and small pockets of latosol with cerrado vegetation. The local climate is characterized by rainy summer and arid winter. The range is recognized as an area of extreme importance for nature conservation within the state of Minas Gerais (PROBIO 2004). Apart from their relatively large species richness, the campo rupestre and forest biotas of the Serra de São José comprise many endemic and endangered species, and this fact alone justifies the range as a priority area for conservation at both the state and federal levels (Alves and Kolbek 2009). Alves and Kolbek (2009) have recently described and discussed the flora and vegetation of the Serra de São José as the result of more than twenty years of research. However, the present study includes more taxa, morphological and ecological descriptions, and a dichotomous key for taxonomic identification.

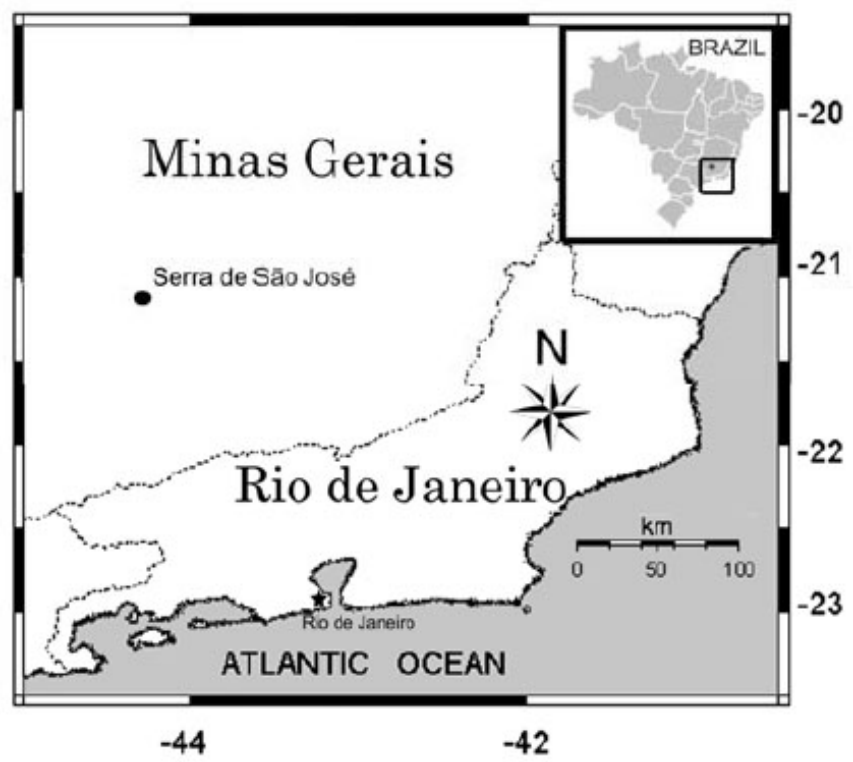

FIGURE 1. Location of the Serra de São José, in Minas Gerais, Brazil.

\section{Data collection}

Field trips were undertaken during all seasons from 2007 to 2009 in order to sample all encountered species, to obtain photographs and to investigate the seasonal behavior of all carnivorous plant taxa. Only the family Lentibulariaceae is treated herein because the Drosera 
species found are still being studied by us. The specimens, either dried or preserved in alcohol, were deposited as vouchers at the Museu Nacional (R) and also at the Universidade de São Paulo (SPF) herbaria.

All ecological and morphological information, including the identification key, were based only on plants and data collected in the study area, except for the flower color of Utricularia pubescens, which was based on samples and observations made in other sites and on literature. Some species were successfully kept alive in cultivation and produced flowers, generating extra material for determination. The identification key was elaborated based mainly on reproductive characters in order to ease the identification due to the lack or meagerness of vegetative parts in many dried herbarium specimens. However, vegetative characters are provided for all species in the diagnoses.

\section{RESUlTS AND DiscusSion}

In the Espinhaço chain, the localities which remain wet for the entire year are limited to the areas directly in contact with the margins of medium to large streams which do not dry up during the cool and arid winter. These sites usually have a considerable amount of decomposing organic matter, but the low plant species richness in some areas covered by dense colonies of Drosera, another carnivorous plant genus, reveal their oligotrophic condition. The acidity of the water which bathes these soils ( $\mathrm{pH} \sim 4.5$ ) also favors the occurrence of perennial species.

On the other hand, the sites subjected to considerable seasonal oscillations of humidity, being waterlogged or at least very wet in the summer and dry in the winter, are inhabited by annual species of Lentibulariaceae. Each year the first rains quickly hydrate the moss layers on the outcrops, especially those which dip northward and are hence more exposed to the sun. On those moss cushions, often composed of Sphagnum sp. and Campylopus sp., seeds of some Lentibulariaceae such as Genlisea violacea and Utricularia amethystina germinate.

In the summer, the shallow sand layer directly overlying bedrock is often saturated to the point at which a thin layer of water covers the substrate, slowly converging into temporary streams. These areas are covered with many Cyperaceae, Eriocaulaceae, Poaceae, and Xyridaceae. In places where these habitats are preserved or only mildly degraded by grazing livestock and fire, annual species such as Utricularia laciniata, Utricularia simulans and Genlisea filiformis can be found. These sites are flat to mildly sloping and occur on the tabletop summits of the range.

A curious habit is that of Utricularia neottioides: the plant adheres to the rocky bottom of active watercourses by means of an apressory, whence it develops submerged runners with few traps. Subsequently it emits inflorescences which protrude above the water surface. This species forms dense colonies and the dried remains of it can still be observed attached to the bedrock during the dry season.

Based on previous floristic surveys in the area (part of the $\mathrm{PhD}$ thesis of the second author), on earlier collections in herbaria and on the results of many recent expeditions, thirteen species of Lentibulariaceae were found, three of them belonging to the genus Genlisea A. St.-Hil. and 10 to the genus Utricularia L. These numbers reveal the richness of the species composition on this relatively small mountain range.

Though both of these genera have aerial organs of similar appearance and size, they can be distinguished by the number of sepals, 5 in Genlisea and two (rarely three) in Utricularia, and by the shape of the utriclebearing leaf which is a relatively simple in Utricularia, but rather elongated and having delimited regions in Genlisea (Fromm-Trinta 1996).

\section{KEY TO LENTIBULARIACEAE SPECIES FROM SERRA DE SÃo José:}

1. Calyx with 5 lobes. Trap as an elongate bifurcate spiral . 2 (Genlisea spp.)

1'. Calyx with 2 lobes (rarely 3). Trap vesicular. ..4 (Utricularia spp.)

2. Corolla purple/violet. Spur nearly parallel to the pedicel. Fruit with longitudinal dehiscence. ................... G. violacea 2'. Corolla yellow. Spur nearly parallel to the lower lip. Fruit with circumsissile dehiscence. 3

3. Spur with apex from truncate to subtruncate, as long as the lower lip. Pedicels sparsely covered with trichomes..... G. filiformis

3'. Spur with apex from obtuse to acute, noticeably longer than the lower lip. Pedicels densely covered by trichomes.

G. pygmaea

4.Corolla white or greenish. ......................................... 5

$4^{\prime}$.Corolla yellow or violet/purple. ................................... 8

5. Lower lip entire. ................................................... 6

$\mathbf{5}^{\prime}$. Lower lip 3-lobed. ................................................... 7

6. Calyx lobes entire. ....................................... pubescens 6'. Calyx lobes laciniate. .................................... Simulans

7. Corolla white or greenish. Spur short and curved, not exceeding the lower lip...................................... neottioides $7^{\prime}$. Corolla white. Spur long and straight, conspicuously exceeding the lower lip................................... amethystina

8. Corolla yellow. ..................................................... 9

$\mathbf{8}^{\prime}$.Corolla purple/violet. ...............................................13

9. Calyx laciniate. ............................................. simulans

$\mathbf{9}^{\prime}$. Calyx entire. ....................................................... 10

10. Spur with obtuse apex, approximately twice as long as the lower lip. U. amethystina

$10^{\prime}$. Spur with acute or acuminate apex, as long as or up to $1 / 3$ shorter or longer than the lower lip. ........................ 11

11. Calyx lobes with conspicuous nerves converging at the apex, which is acute. U. triloba 11'. Calyx lobes without prominent nerves towards the apex, which is rounded. 12 
12. Inflorescence reaching more than $20 \mathrm{~cm}$ in height. Corolla over $7,5 \mathrm{~mm}$ wide. U. nervosa

12'. Inflorescence less than $20 \mathrm{~cm}$ in height. Corolla less than $7.5 \mathrm{~mm}$ wide.

U. subulata

13. Lower lip deeply 3-lobed. U. amethystina

13'. Lower lip entire or slightly 3-lobed. 14

14. Palate with a yellow and white spot. Petiole conspicuous, flat. Scales, bracts and bracteoles with entire margins. Fruit dehiscent by two valves.

U. tricolor

$1^{\prime}$. Palate with a completely yellow spot or without a spot. Petiole inconspicuous or from cylindric to funnel-shaped. Scales, bracts and bracteoles with margins not entire. Fruit dehiscent by a longitudinal ventral slit. 15

15. Leaves orbicular or suborbicular. Petiole from cylindric to funnel-shaped. Scales few, without dimorphism, entire. Spur with obtuse apex. U. pubescens 15'. Leaves linear. Petiole inconspicuous. Scales numerous, the basal laciniate and the apical entire. Spur with emarginated apex. U. laciniata

Obs. As Utricularia cf. reniformis was not sampled in flower yet and considering that the keys to this genus are based mainly on reproductive characters, this taxon is not included in the key. However, it can be distinguished by the vegetative organs, described in the diagnosis.

\section{Genlisea A.St.-Hil.}

Species in the range are small and delicate rhizomatous herbs which inhabit moist places. The aerial leaves are basal, rosulate, and variously covered with trichomes. There are no traces of roots and the rhizome is usually horizontal and reptant. The flowering scape is an erect raceme emitted from the rosette center. The calyx is persistent. The corolla is two-lipped, the lower lip being gibbous and three-lobed. The globose ovary develops into a capsule. This genus was divided into two subgenus by Fischer et al. (2000) based on the sectional concept of From-Trinta (1977): subgenus Genlisea is characterized by species with circumsissile dehiscing fruits, while subgenus Tayloria by species with longitudinally dehiscing capsules.

Three species were found in the study area: Genlisea filiformis, G. pygmaea and G. violacea.

\section{Genlisea filiformis A. St.-Hil. (Figure 2A-B)}

Herb with prostrate leaves forming a small dense rosette of 5-19 $\mathrm{mm}$ in diameter. Inflorescence 2-20 cm in height, the bottom half sparsely covered with nonglandular trichomes and with glandular trichomes from this point to the apex, bearing 1-8 flowers. Calyx almost glabrous or glabrous. Corolla yellow, 1.4-5 mm wide, spur widened and truncate/subtruncate, as long as of the lower lip. Pedicel erect in the flower and fruit. Fruit 1.3-1.9 mm in diameter, dehiscence circumsissiled.

The species description was made by Saint-Hilaire (1833) based on a holotype collected in the Serra de São José itself. It is annual and can be found flowering during the rainy summer months, growing in small groups on flat to mildly sloping open grasslands with seasonally waterlogged sandy soil. Some groups of individuals in the range are smaller than $2 \mathrm{~cm}$ and bear only a single flower per scape. Genlisea filiformis can be distinguished from the other species in the area by the small yellow flowers, obtuse spur apex and by occurring more frequently in temporarily flooded flat grasslands.

Selected examined material: Silva NG 265(R).

\section{Genlisea pygmaea A. St.-Hil. (Figure 2C)}

Herbs with spatulate leaves 3-9.5 mm long. Inflorescence $8-15 \mathrm{~cm}$ in height, covered with intermixed non-glandular and glandular trichomes, bearing 1-6 flowers. Calyx hirsute. Corolla yellow, 6.1-9.2 mm wide, spur noticeably longer than the corolla lower lip. Pedicel erect in the flower and fruit. Fruit 1.9-3.3 mm in diameter, dehiscence circumsissiled.

This species can survive the drier seasons by producing small tubers, which were observed by us in the study area and by Rivadavia (2007) in other sites. It grows in humid sandy soil, together with grasses. Differs from other species of the genus in the range by having yellow corolla and an acuminate spur.

Selected examined material: Silva NG 277(R).

\section{Genlisea violacea A. St.-Hil. (Figure 2D)}

Herbs with a relatively sparse basal leaf rosette with 8-24 $\mathrm{mm}$ in diameter. Inflorescence $5-17 \mathrm{~cm}$ in height, densely covered with glandular trichomes, bearing 2-8 flowers. Calyx hirsute. Corolla violet with yellow palate, 3.5$6 \mathrm{~mm}$ wide. Spur nearly cylindrical, parallel to the pedicel. Pedicel erect in flower and reflexed in fruit. Capsule with 2-3.7 $\mathrm{mm}$ in diameter, with longitudinal dehiscence.

This annual species can be seen flowering in groups, growing on moss cushions directly over rock outcrops. It is the only violet flowered Genlisea sampled in the area. Selected examined material: Silva NG 191; Silva NG 259(R).

\section{Utricularia L.}

Species in the Serra de São José are herbs which grow in humid sand, on peat and other moss cushions or adhered to the rocky bottom of flowing water streams. These plants have leaves of various shapes, usually small and positioned very close to, or often even partly buried or submerged in the substrate. The scapes are bracteate racemes bearing one to several flowers, white, yellow or purple/violet. The calyx is bilobed, with unequal lobes. The spur is relatively parallel to the lower corolla lip.

To date, 10 species have been found on the Serra de São José: Utricularia amethystina, U. laciniata, U. neottioides, $U$. nervosa, U. pubescens., U. simulans, U. subulata, U. tricolor, $U$. triloba and $U$. cf. reniformis.

Utricularia amethystina Salzm ex. A. St.-Hil. \& Girard (Figure 3A-C)

Annual or perennial herb with obovate, spatulate or suborbicular leaves. Inflorescence $1-21 \mathrm{~cm}$ in height, bearing 1-5 flowers. Corolla 4-10.5 mm wide, white, yellow or light-purple, lower lip 3-lobed, spur approximately two or three times as long as the lower lip. Palate yellow or white. Fruit with $1.5-2.8 \mathrm{~mm}$ in diameter, dehiscent by two valves. 
This is an excessively polymorphic taxon, with considerable variations in overall size, color, corolla dimensions, scape height, number of flowers and reproductive cycle duration (Taylor, 1989). Part of these morphological variations may be due to natural hybridization. This species grows in sandy plains, mosses or stream margins. It can be distinguished from the other species in the area by the shape and dimension of the spur and corolla lower lip. Four distinct morphotypes were found (Table1).

Selected examined material: Silva NG 272, 276, 278(R).

TABLE 1. Morphological variation of Utricularia amethystina in the Serra de São José mountain range.

\begin{tabular}{cccc}
\hline $\begin{array}{c}\text { Corolla } \\
\text { Color }\end{array}$ & $\begin{array}{c}\text { Corolla } \\
\text { Width }\end{array}$ & $\begin{array}{c}\text { Palate } \\
\text { Color }\end{array}$ & $\begin{array}{c}\text { ScaPE } \\
\text { Height }\end{array}$ \\
\hline White & $<5 \mathrm{~mm}$ & White (not distinctive) & $<5 \mathrm{~cm}$ \\
White & $>8 \mathrm{~mm}$ & Yellow & $>10 \mathrm{~cm}$ \\
Yellow & $>6 \mathrm{~mm}$ & Yellow (not distinctive) & $>10 \mathrm{~cm}$ \\
Pale Purple & $>6 \mathrm{~mm}$ & Yellow & $>10 \mathrm{~cm}$ \\
\hline
\end{tabular}

\section{Utricularia laciniata A. St.-Hil. \& Girard (Figure 3D)}

Annual herb with linear or spatulate leaves of 3-8 mm long. Inflorescence 5-8 cm in height bearing 1-4 flowers. Calyx denticulate. Corolla 5-6 mm wide, pale to dark violet with a yellow spot in the center of the lower lip, which is entire. Palate flattened with a yellow horizontal stripe. Spur and lower lip of approximately equal lengths. Scales and bracts laciniate. Fruit ca. $1.5 \mathrm{~mm}$ in diameter, dehiscing by a longitudinal ventral slit.

This annual species is not common in the study area. It grows in seasonally humid sandy meadows, with a low herb layer without trees. This species can be distinguished by the violet corolla, entire lip and laciniate bracts.

Selected examined material: Drummond RAR 148-b(R); Silva NG 194(R).

\section{Utricularia neottioides A. St.-Hil. \& Girard (Figure 3E)}

Annual rheophytic herb with verticillate stolons with branches divided into leafy segments. Inflorescence 4-20 cm in height, bearing 3-20 flowers with a mild sweetish fragrance. Corolla white or pale green, 1.7$3.2 \mathrm{~mm}$, upper lip entire, lower lip deeply three-lobed with lobes of equal length. Palate elevated, without conspicuous pigmentation. Spur short, curved and rounded. Fruit 1-1.5 $\mathrm{mm}$ in diameter, dehiscing by an oblong ventral pore.

The plants grow attached to the rocky bottoms of streams or rock outcrops with running water, forming dense colonies, even in areas of relatively strong current. It can be distinguished from the other species in the study area by its rheophytic habit and by the short, curved and rounded spur.

Selected examined material: Silva NG 188(R).

\section{Utricularia nervosa G. Weber ex. Benj. (Figure 3F)}

Perennial plant with entire or asymmetrically divided, narrowly spatulate leaves with 4-29 mm long and 0.5$1.2 \mathrm{~mm}$ wide. Inflorescence long and flexuous, $22-41 \mathrm{~cm}$ in height, bearing 2-7 flowers. Calyx lobes sub equal, the lower bigger, nerves conspicuous. Corolla yellow, 7.3-13 mm wide; lower lip three-lobed. Spur longer than the lower corolla lip, with acuminate apex. Fruit 1.9-2.3 mm, dehiscent by a ventral elliptic pore.

This species grows in humid rock slits in margins of streams and in sandy grass-covered plains. U. nervosa resembles $U$. subulata but can be distinguished mainly by the relative overall size of the plants.

Selected examined material: Alves RJV 941(R); Silva NG 331(R).

\section{Utricularia pubescens Sm. (Figure 4A)}

Perennial herb with glandular and papillose peltate leaves, lamina orbicular or suborbicular with 1-8 mm wide. Inflorescence $2-20 \mathrm{~cm}$ in height, bearing 2-4 flowers. Calyx lobes sub equal. Corolla from white to violet/purple, 2-6 mm wide, with or without a yellow macula in the middle of the lower lip. Palate of the same color of corolla or with a yellow spot. Spur conical with obtuse apex, shorter or longer than the lower lip. Fruit ca. $1.5 \mathrm{~mm}$ in diameter, dehiscing by longitudinal ventral slit.

$U$. pubescens grows in organic soil on partly shaded stream margins together with $U$. tricolor. The leaves grow adpressed to the substrate with petioles buried into the soil. Despite the fact that this species was not yet sampled in flower (U. pubescens is known to flower quite rarely) in the Serra de São José, the aforementioned peculiar vegetative characters allow the determination to species level with certainty. All the reproductive structures described were based on the additional material.

Selected examined material: Silva NG 335(R).

Additional material examined: Ule E. s.n. (R); Brade AC 20226 (R).

\section{Utricularia simulans Pilg. (Figure 4B)}

Annual herb with lanceolate, oblong or narrowly spatulate leaves of 3-8 mm long. Inflorescence glabrous, 2-15 cm in height, bearing 1-8 flowers congested at the apex. Calyx deeply laciniate. Corolla yellow or white, 2.8-5 mm wide, lower lip entire. Spur conical with obtuse apex, usually concealed by the lower lip. Palate protruding, without distinctive pigmentation. Fruit ca. $2 \mathrm{~mm}$ in diameter, dehiscing by a longitudinal ventral slit.

This annual species grows in seasonally moist sandy soils and can be easily distinguished by the deeply laciniate calyx, yellow flowers congested at the apex and entire lower lip.

Selected examined material: Alves RJV 335(R); Silva NG 260(R).

\section{Utricularia subulata L. (Figure 4C)}

Annual or perennial herbs with narrowly spatulate leaves 2-16 mm long. Inflorescence glabrous and flexuous, 3-16 cm in height, bearing 1-6 flowers. Calyx lobes ovate, the nerves are prominent but do not gather in the apex, which are rounded. Corolla yellow, 3-7.5 mm wide, upper lip entire, lower lip varyingly three-lobed. Spur as long as the lower lip or slightly longer or shorter. Fruit 0.9-1.4 mm in diameter, dehiscent by means of an oval-shaped ventral pore.

Grows in almost all humid and sunny environments of 
the study area, including moss, sand or stream margins. This species can be found flowering during all seasons, as long as the locality remains humid. Considerable variations have been observed in overall size, flower size, depth of the division of lower lip and spur size (Taylor, 1989). Cleistogamy frequently occurs. U. subulata resembles $U$. triloba, but has sepals with a rounded apex with nerves visible only in the basal $1 / 2-2 / 3$ (while sepals of $U$. triloba have an acute apex at which the noticeable nerves converge). U. nervosa is also similar, but has bigger flowers and scapes.

Selected examined material: Silva NG 256(R).

\section{Utricularia tricolor A. St.-Hil. (Figure 4D)}

Perennial herb with ovate or obovate leaves. Inflorescence long and thickened, $18-30 \mathrm{~cm}$ tall, green or pale to dark purple, bearing 1-2 flowers. Calyx lobes sub equal, glabrous. Corolla purple/violet with upper lip entire and lower broadly rounded or indistinctly threelobed, 11-30 mm wide. Palate with a yellow and white macula. Spur with acute apex, shorter or longer than the lower lip. Fruit 3-4 $\mathrm{mm}$ in diameter, dehiscing by two valves.

This species is confined to shady stream banks which remain humid during the dry winter. It can be distinguished mainly by the characteristics of the corolla and by the fact that it produces lots of anomalously-branched scapes which do not develop flowers.

Selected examined material: Silva NG 250(R).
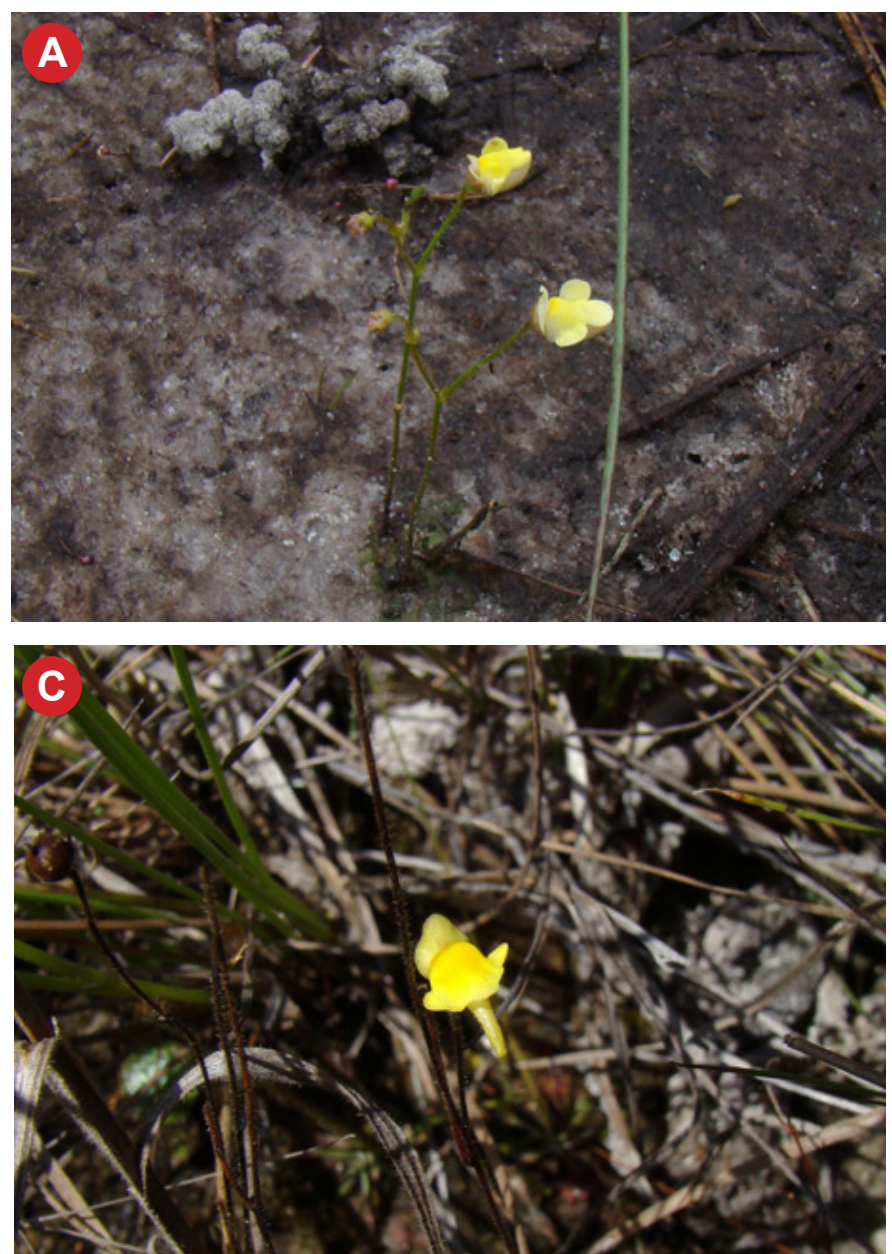

\section{Utricularia triloba Benj. (Figure 4E)}

Annual or perennial herb with entire or asymmetrically divided narrowly spatulate or elliptic leaves. Inflorescence flexuous, bearing 1-3 flowers. Calyx lobes sub-equal, conspicuously 5-nerved with the nerves converging at the acute apex. Corolla yellow, 7.8-8 mm wide, upper lip entire, lower lip entire or 3-lobed. Spur thickened with apex acuminate or less commonly rounded. Fruit with 1-6 mm in diameter, dehiscing by an elliptic ventral pore.

This species grows in almost all humid parts of the study area, with preference for peat soils. It can be distinguished from $U$. subulata mainly by the calyx lobes characteristics (see $U$. subulata description).

Selected examined material: Silva NG 266(R).

\section{Utricularia cf. reniformis A. St.-Hil (Figure 4F-H)}

Perennial lithophytic plant with glandular kidneyshaped or auriculate leaves. Lamina reaching $25 \mathrm{~mm}$ in width. Petioles conspicuous, delicate. Stolons branched. Traps reaching $1.1 \mathrm{~mm}$ in diameter.

This species was found at a single shady locality, growing together with $U$. pubescens, in shallow, organic soil on the margins of a persistent pool in a deep ravine cut by a seasonal stream (with stagnant water at the time of sampling). Only fertile material shall elucidate this specimen entirely, although it strongly appears to be $U$. reniformis.

Selected examined material: Silva NG 336(R).
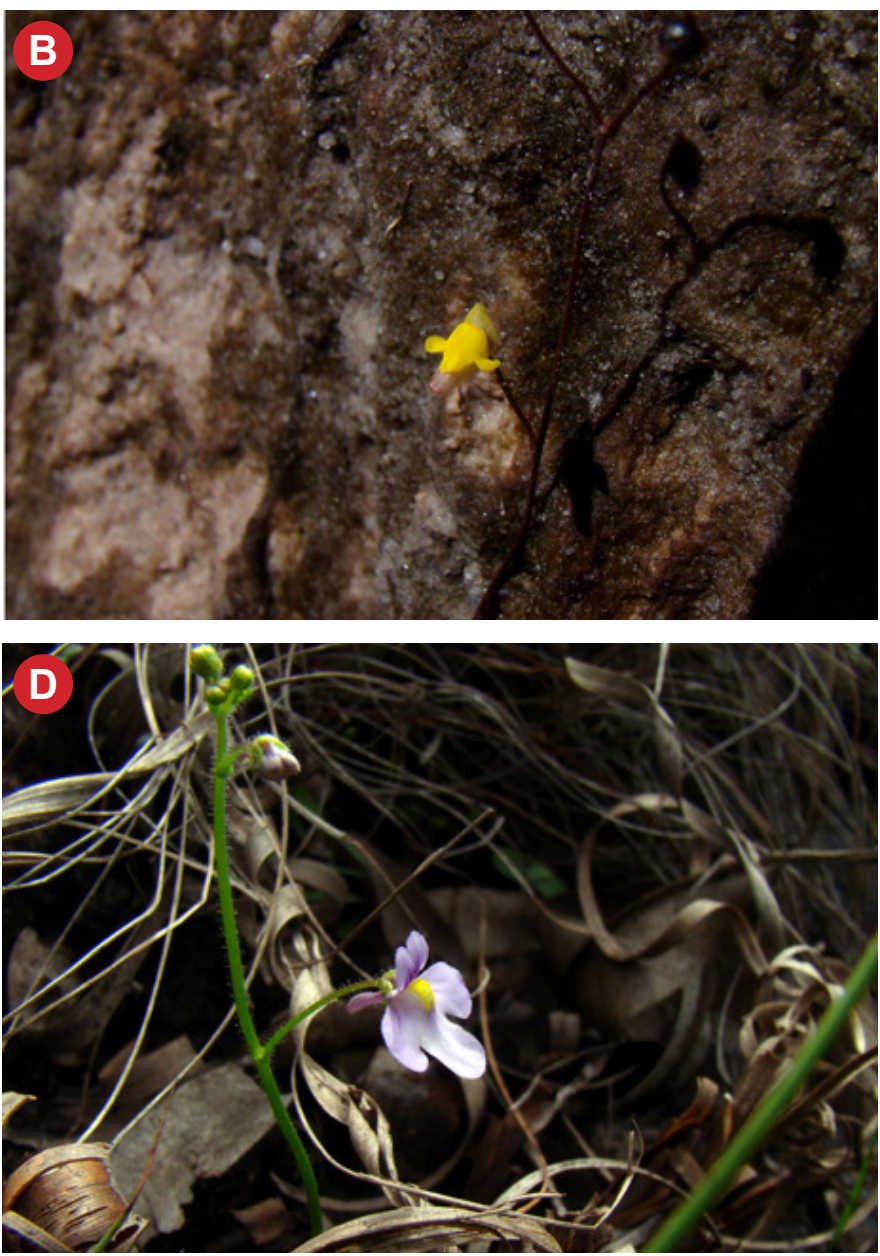

Figure 2. Genlisea species of the Serra de São José, MG, Brazil. A and B: G. filiformis; C: G. pygmaea; D: G. violacea. 

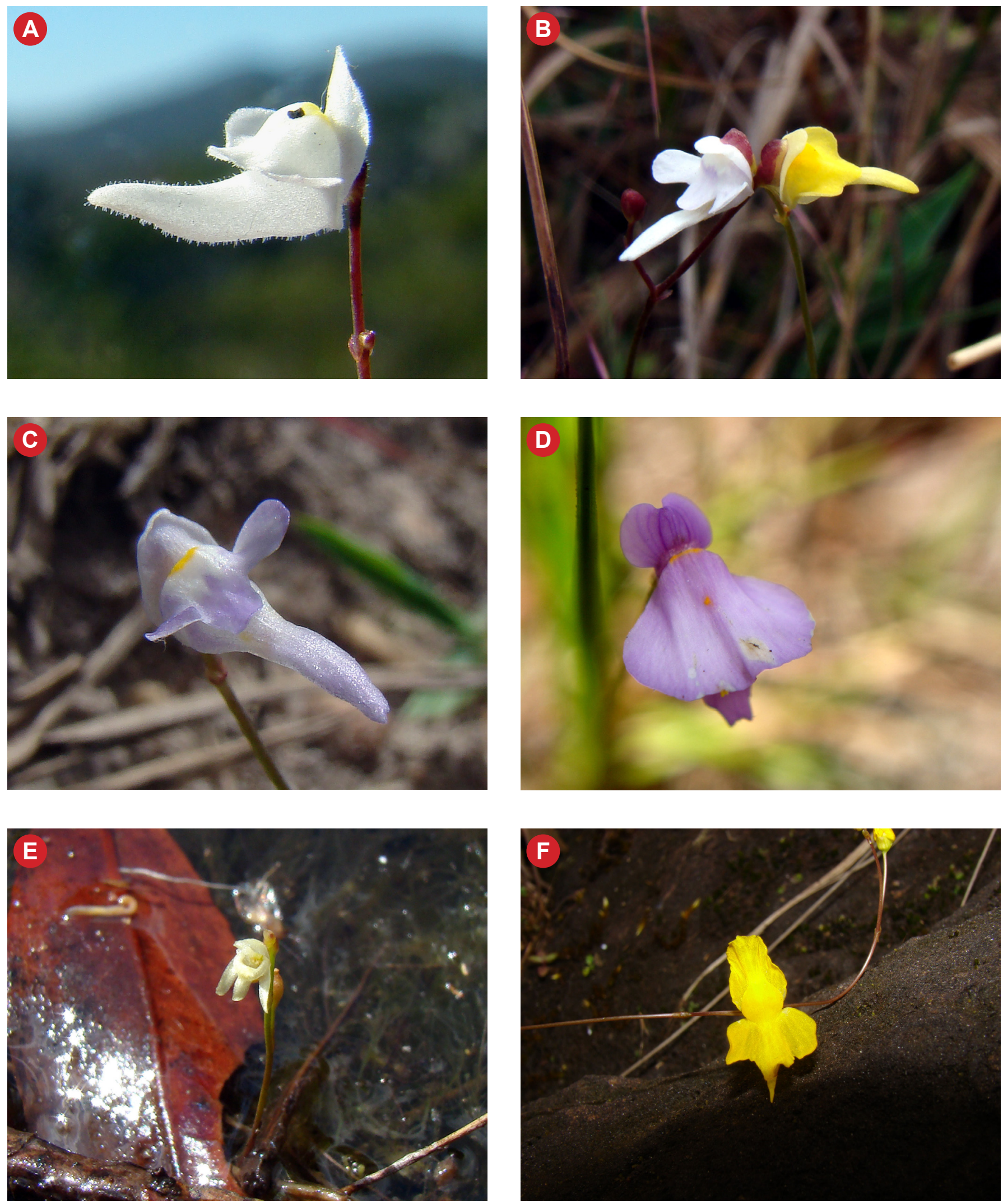

FiguRE 3. Four Utricularia species of the Serra de São José, MG, Brazil. A, B and C: U. amethystina; D: U. laciniata; E: U. neottioides; F: U. nervosa. 

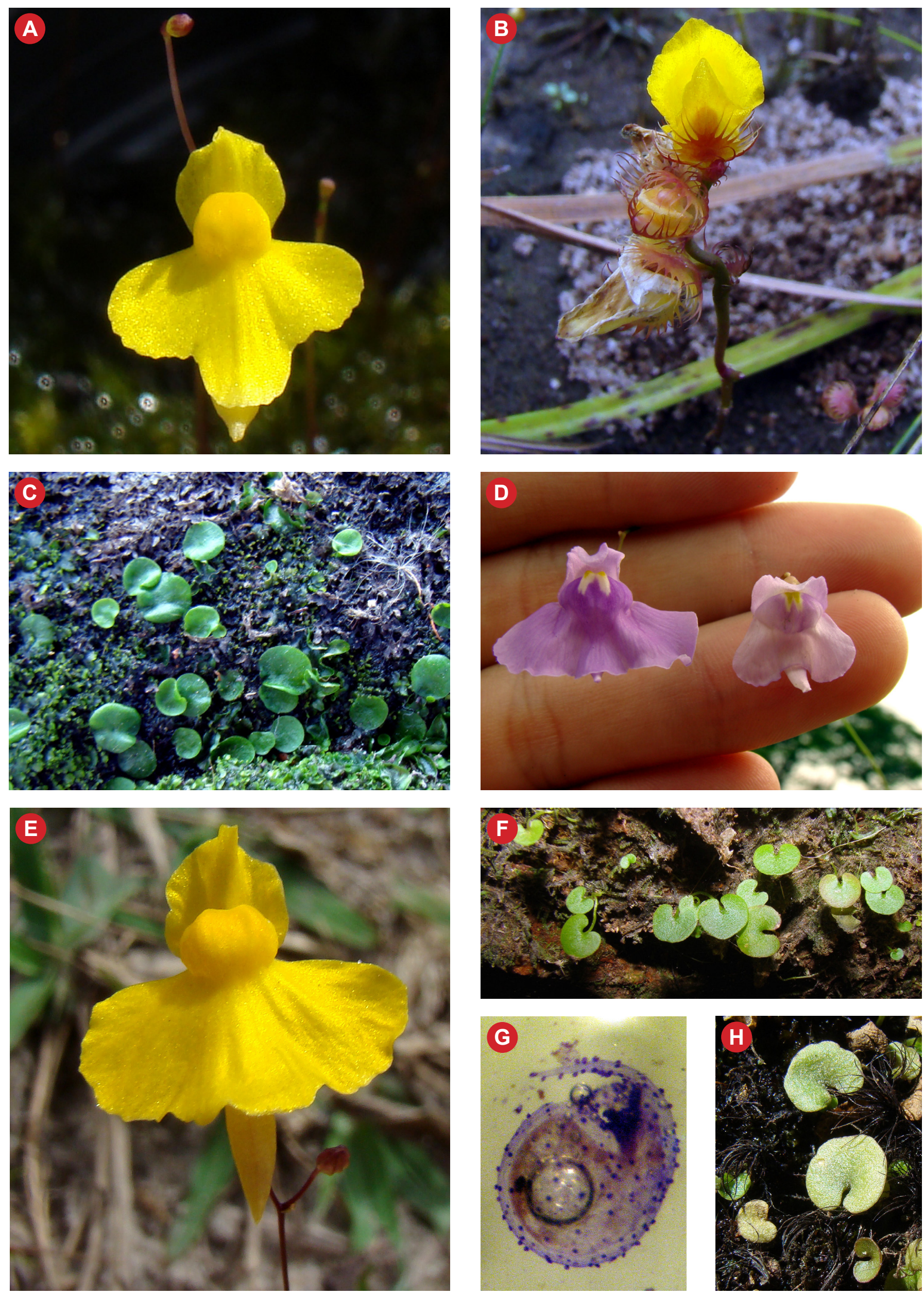

FigURE 4. Six Utricularia species of the Serra de São José, MG, Brazil. A: U. subulata; B: U. simulans; C: U. pubescens; D: U. tricolor; E: U. triloba; F, G and H: Utricularia cf. reniformis. (G: Trap dyed with methylene blue). 
ACKNOWLEDGMENTS: Authors are thankful to Ana Paula Pinheiro, Janaína Aguiar, and Itamar Christófaro Silva from the IEF-MG; Pedro Fernandes, Roberto Franco-Junior, Paulo Gonella, Dra. Maria Helena Baeta Neves, Dr. Miloslav Studnička, Dra. Cláudia Bove, Dr. Vitor Miranda, Dra. Cássia Sakuragui, Dra. Luci de Senna-Valle, Dra. Bárbara de Sá Haiad, Paulo Baleeiro and Silmara Bergamo for the logistic support, accompanying field work, knowledge sharing, dissertation revision, and kindness; Adalmo Gomes da Silva for essential help with the cultivation and to the Conselho Nacional de Desenvolvimento Científico e Tecnológico (CNPq)

for conceding research grants to the first and second authors.

\section{LITERATURE CITED}

Alves, R.J.A. and Kolbek, J. 2009. Summit vascular flora of Serra de São José, Minas Gerais, Brazil. Chek List 5(1): 35-73.

Fischer, E., S. Porembski, and W. Barthlott. 2000. Revision of the genus Genlisea (Lentibulariaceae) in Africa and Madagascar with notes on ecology and phytogeography. Nordic Journal of Botany. 20: 291-318.

Fromm-Trinta, E. 1977. Tayloria Fromm-Trinta - Nova Seção do gênero Genlisea St.-Hil. (Lentibulariaceae). Boletim do Museu Nacional 44: $1-4$
Fromm-Trinta, E. 1996. Flora da Serra do Cipó, Minas Gerais: Lentibulariaceae. Boletim de Botânica da Universidade de São Paulo $14: 105-118$

PROBIO. 2004. Áreas prioritárias para a conservação, utilização sustentável e repartição de benefícios da Biodiversidade BrasileiraProjeto de Conservação e Utilização Sustentável da Diversidade Biológica Brasileira. Brasília: Ministério do Meio Ambiente. CD ROM.

Rivadavia. 2007. A Genlisea Myth is Confirmed. Carnivorous Plants Newsletter 36(4): 122-125.

Saint-Hilaire, A. 1833. Voyage dans le District des Diamans et sur le Littoral du Bresil. Paris: Gide. 54 p.

Taylor, P. 1989. The genus Utricularia - a taxonomic monograph. Kew Bulletin Additional Series 14: 724p.

RECEIVED: August 2010

LAST REVISED: October 2010

ACCEPTED: February 2011

PUBLISHED ONLINE: March 2011

EDITORIAL RESPONSIBILITY: Frederico Augusto Guimarães Guilherme 